\title{
Erratum to: Stereotypes, prejudices and exclusion of Fulani pastoralists in Ghana
}

\author{
Kaderi Noagah Bukari ${ }^{1,2^{*}}$ and Nikolaus Schareika ${ }^{2}$
}

\section{Erratum}

Following publication of the original version [1] of the article of the Pastoralism Journal 2015, it was bought to our attention that an authors name was incorrectly published. The authors name should be presented as "Nikolaus Schareika" and not "Nicholaus Schareika".

Received: 10 November 2015 Accepted: 12 November 2015

Published online: 30 November 2015

\section{Reference}

1. Bukari, KN, and N Schareika. 2015. Accrediting retail drug shops to strengthen Tanzania's public health system: an ADDO case study. Pastoralism 5:20

\footnotetext{
* Correspondence: kaderibukari2009@gmail.com

'Center for Development Research (ZEF), University of Bonn, Walter-Flex-Straße 3, Bonn 53113, Germany

${ }^{2}$ Institute of Social and Cultural Anthropology, University of Göttingen, Theater Platz 15, Göttingen 37073, Germany
}

Submit your manuscript to a SpringerOpen ${ }^{\odot}$ journal and benefit from:

- Convenient online submission

- Rigorous peer review

- Immediate publication on acceptance

- Open access: articles freely available online

- High visibility within the field

- Retaining the copyright to your article

Submit your next manuscript at $\boldsymbol{\wedge}$ springeropen.com

\section{Springer}

(c) 2015 Bukari and Schareika. Open Access This article is distributed under the terms of the Creative Commons Attribution 4.0 International License (http://creativecommons.org/licenses/by/4.0/), which permits unrestricted use, distribution, and reproduction in any medium, provided you give appropriate credit to the original author(s) and the source, provide a link to the Creative Commons license, and indicate if changes were made. 